\title{
PENGARUH FASILITAS KERJA, KONFLIK PERAN, MOTIVASI KERJADAN KECERDASAN EMOSIONAL TERHADAP KINERJA PEGAWAI PADA KANTOR PELAYANAN PAJAK PRATAMA TEBING TINGGI
}

\author{
Endar Khairul Daulay \\ Universitas Islam Sumatera Utara \\ endar.daulay@gmail.com
}

\begin{abstract}
The problems in this research are: How is the influence of work facilities, role conflict, work motivation and emotional intelligence partially and concurrently on the performance of employees in the Primary Tax Office Tebing Tinggi? Research objectives: To determine the effect of work facilities, role conflict, motivation and emotional intelligence partially and simultaneously on the performance of employees in the Primary Tax Office Tebing Tinggi. The hypothesis proposed is: There is a significant effect of work facilities, role conflict, work motivation and emotional intelligence partially and jointly on the performance of employees in the Primary Tax Office Tebing Tinggi. The study was conducted at the Pratama Tebing Tinggi Tax Service Office Jalan Sutoyo Number 32 Rambung Tebing Tinggi, with a population of 83 people, and a study sample. of 82 people.

Based on the analysis results obtained work facilities have a positive and significant effect on the performance of the Primary Tax Service Office Tebing Tinggi, this is supported by the results of $t$ count analysis>t-table (1.953> 1.67) at $n=82$ at 95\% significance level. Role conflict has a negative and significant effect on the performance of the Primary Tax Service Office of Tebing Tinggi, this is supported by an analysis of $t$ count $>t$-table $(0.112<1.67)$ at $n=82$ at $95 \%$ significance level. Work motivation has a positive and significant effect on the performance of the Tebing Tinggi Primary Tax Office employee, this is supported by an analysis of $t$ count $>t$-table (3.53> 1.67) at $n=82$ with a significant level of 95\%. Emotional intelligence has a positive and significant effect on the performance of the Primary Tax Service Office of Tebing Tinggi, this is supported by the results of thitung analysis>t-table $(4.01>1.67)$ at $n=82$ with a significance level of 95\%.Value of F-count $>F$ table $(138,565>2,48)$ This states that together (multiple) there are positive and significant effects of work facilities, role conflict, work motivation and emotional intelligence on the performance of employees of the Pratama Tebing Tinggi Tax Office. Thus the hypothesis proposed is accepted by the truth
\end{abstract}

Keyworld: Work facilities, role conflict, work motivation and emotional intelligence and employee performance

ABSTRAK : Masalah dalam peneltian ini adalah: Bagaimana pengaruh fasilitas kerja, konflik peran, motivasi kerja dan kecerdasan emosional secara parsial dan bersamaan terhadap kinerja pegawai di Kantor Pelayanan Pajak Pratama Tebing Tinggi ? Tujuan penelitian : Untuk mengetahui pengaruh fasilitas kerja, konflik peran, motivasi dan kecerdasan emosional secara parsial dan secara bersamaan terhadap kinerja pegawai di Kantor Pelayanan Pajak Pratama Tebing Tinggi. Hipotesis yang diajukan adalah : Ada pengaruh yang signifikan fasilitas kerja, konflik peran, motivasi kerja dan kecerdasan emosi secara parsial dan secara bersama-sama terhadap kinerja pegawai di Kantor Pelayanan Pajak Pratama Tebing Tinggi. Penelitian dilakukan di Kantor Pelayanan Pajak Pratama Tebing Tinggi Jalan Sutoyo Nomor 32 Rambung Tebing Tinggi, dengan populasi sebanyak 83 orang, dan sampel penelitian sebanyak 82 orang. Berdasarkan hasil analisis diperoleh Fasilitas kerja berpengaruh positip dan signifikan terhadap kinerja pegawai Kantor Pelayanan Pajak Pratama Tebing Tinggi, hal ini didukung hasil analisis $t$ hitung > t-tabel $(1,953>1,67)$ pada $n=82$ pada taraf sifgifikansi $95 \%$. Konflik peran berpengaruh negatif dan signifikan terhadap kinerja pegawai Kantor Pelayanan Pajak Pratama Tebing Tinggi, hal ini didukung analisis thitung $>t$-tabel $(0,112<1,67)$ pada $n=82$ pada taraf 
sifgnifikansi 95\%. Motivasi kerja berpengaruh positif dan signifikan terhadap kinerja pegawai Kantor Pelayanan Pajak Pratama Tebing Tinggi, hal ini didukung analisis thitung > t-tabel (3,53 $>1,67)$ pada $n=82$ dengan taraf sifgnifikan 95\%. Kecerdasan emosional berpengaruh positif dan signifikan terhadap kinerja pegawai Kantor Pelayanan Pajak Pratama Tebing Tinggi, hal ini didukung hasil analisis thitung > t-tabel $(4,01>1,67)$ pada $n=82$ dengan taraf sifgifikan $95 \%$. Nilai F-hitung > F tabel $(138,565>2,48)$ hal ini menyatakan bahwa secara bersama-sama (multiple) terdapat pengaruh positif dan signifikan fasilitas kerja, konflik peran, motivasi kerja dan kecerdasan emosional terhadap kinerja pegawai Kantor Pelayanan Pajak Pratama Tebing Tinggi. Dengan demikian hipotesis yang diajukan diterima kebenarannya.

Keyworld : Fasilitas kerja, konflik peran, motivasi kerja dan kecerdasan emosional serta kinerja pegawai.

\section{Pendahuluan}

Untuk mencapai tujuan organisasi tidak lepas dari kinerja manusia yang ada dalam organisasi. Kinerja merupakan hasil kerja yang dicapai oleh seseorang dalam bidang pekerjaanya menurut kriteria tertentu yang berlaku untuk suatu pekerjaan tertentu dan di evaluasi oleh orang-orang tertentu. Oleh sebab itu berhasil tidaknya organisasi seperti Kantor Pelayanan Pajak Pratama Tebing Tinggi dalam mencapai tujuannya tidak lepas dari kinerja organisasi. Kinerja pegawai dipengaruhi oleh beberapa faktor seperti kepemimpinan, motivasi, kemampuan pegawai, sikap dan perilaku serta disiplin dan lain sebagainya. Meskipun pegawai memiliki kemampuan dan keterampilan jika tidak didukung dengan fasilitas kerja maka pegawai tidak akan dapat mencapai kinerja yang tinggi, Karena fasilitas kerja sangat mendukung tercapainya pelaksanaan pekerjaan dan penyelesaian pekerjan dengan baik sehingga pada akhirnya diperoleh kinerja yang baik. Fasilitas kerja di Kantor Pelayanan Pratama Tebing Tinggi boleh dikatakan belum cukup secara maksimal akibatnya pegawai terkadang tidak dapat menyelesaikan pekerjaan sesuai dengan yang diharapkan, sehingga tidak tercapanya kinerja yang baik hal ini kurangnya fasilitas kerja seperti kurang cukupnya peralatan misalnya komputer yang anggih dan lain sebagainya.

Faktor lain yang mempengaruhi kinerja pegawai adalah konflik kerja. Konflik sering terjadi dalam kehidupan sehari-hari begitu juga dalam organisasi atau organsasi antara pimpinan dan bawahan dan antara sesama pegawai. Pada dasarnya sulit untuk merumuskan konflik, dalam kenyataan karena dalam kenyataan banyak macam konflik berkaitan dengan setiing/tempat dan berkaitan dengan persoalan, ketidak sesuaian pendapat, kontradiksi atau ketidak selarasan. Konflik antara pegawai dengan pegawai atau departemen-departemen pada tingkat interaksi sesama merupakan konflik horizontal. Salah satu penyebab fundamental konflik adalah tekanan untuk suboptimasi pada kebanyakan organisasi. Para staf cenderung mermiliki tingkat pendidikan lebih tinggi dan mereka berasal dari berbagai macam latar belakang dan mereka umumnya lebih muda dibandingkan dengan para pegawai lama. Ciri pribadi yang berbeda tersebut kerapkali dikaitkan dengan nilai-nilai dan keyakinan-keyakinan yang berbeda, munculnya nilai-nilai yang berbeda ke permukaan cenderung menciptakan situasi konflik. Dalam organisasi pimpinan sangat berperan penting untuk mengusahakan supaya tidak terjadi konflik paling tidak meminimalisir Karena konflik dapat menghambat pencapaian kinerja organisasi.

Selanjutnya peran pimpinan dalam menciptakan perilaku yang khas dari suatu organisasi sangat penting artinya bagi konsep keunggulan kompetitif melalui SDM, dan harus diberi motivasi sebagai daya pendorong yang merangsang pegawai untuk mau bekerja dengan giatnya, sehingga produktivitas kerja pegawai dapat meningkat yang akhirnya prestasi kerja meningkat. Akan tetapi dorongan atau motivasi yang diberikan berbeda antara pegawai yang satu dengan pegawai yang lain. Perbedaan itu disebabkan oleh perbedaan motif, tujuan dan kebutuhan masing-masing pegawai. Bagi setiap pegawai motivasi tidak hanya berwujud kebutuhan ekonomi saja, tetapi bisa berbentuk penghargaan dari lingkungan, status sosial yang semuanya merupakan ganjaran sosial yang sifatnya non materil. Karena manusia tidak sama dengan mesin, maka harus senantiasa dimotivasi untuk bekerja. Pimpinan tidak dapat mengharapkan bahwa motivasi pegawai akan muncul secara spontan. Motivasi berkaitan erat dengan kebutuhan pegawai oleh karena itu 
pemberian motivasi harus bertitik tolak dari kebutuhan pegawai itu sendiri. Pemberian motivasi yang tidak sesuai hanya akan memberikan kekecewaan bagi si pegawai itu sendiri.

Pada mulanya kecerdasan hanya berkaitan dengan kemampuan struktur akal (intelek) dalam menangkap gejala sesuatu, sehingga kecerdasan hanya bersentuhan dalam aspekaspek kognitif namun pada perkembangan berikutnya disadari bahwa kehidupan manusia bukan semata-mata memenuhi struktur akal, melainkan terdapat kalbu yang perlu mendapat tempat tersendiri untuk menumbuhkan aspekaspek afektif seperti kehidupan emosional, moral, spiritual, dan agama. Pada saat ini orang tidak hanya mengenal kecerdasan intelektual, akan tetapi ada kecerdasan lain yang diperhitungkan, diantaranya kecerdasan emosional, kecerdasan spiritual dan kecerdasan qalbiyah. Sesungguhnya kecerdasan emosional adalah kecerdasan yang merujuk pada kemampuan untuk memahami persoalan diri masing-masing dan perasaan orang lain, kemampuan untuk memotivasi dirinya sendiri dan menata dengan baik emosi-emosi yang muncul dalam dirinya dan dalam hubungannya dengan orang lain.

Kantor Pelayanan Pajak Pratama Tebing Tinggi merupakan suatu Instansi pemerintah yang tidak terpisahkan dari keseluruhan proses pelaksanaan pembangunan di wilayah pemerintah Tebing Tinggi pada khususnya dan pembangunan nasional pada umumnya yang diarahkan untuk mewujudkan cita-cita luhur bangsa Indonesia untuk menuju masyarakat yang adil, makmur, sejahtera, mandiri dan bermartabat. Untuk mencapai cita-cita dan tujuan Kantor Pelayanan Pajak Pratama Tebing Tinggi tentu harus didukung oleh kinerja pegawai.

Observasi di lapangan sementara berkaitan kinerja pegawai di Kantor Pelayanan Pajak Pratama Tebing Tinggi boleh disebutkan belum maksimal sebagaimana yang diharapkan, hal ini menurut penulis sebagaimana telah disebutkan di atas akibat fasilitas kerja belum menunjukkan fasilitas yang sesuai atau belum tepat sehingga banyak pegawai yang tidak dapat menyelesaikan tugasnya dengan baik sebagaimana yang ditentukan akhirnya kierja pegawai tidak seperti yang diharapkan. Fasilitas kerja memang sudah tersedia akan tetapi fasilitas kerja boleh dikatakan belum maksimal sehingga pegawai tidak dapat menyelesaikan pekerjaan yang diemban kepadanya tepat dengan waktu dan sesuai yang diharapkan Fasilitas kerja mempunyai hubungan yang erat dengan kinerja. Meskipun pegawai memiliki keterampilan dan pengetahuan yang luas tentang tugas yang diembannya apabila fasilitas kerja tidak cukp atau tidak dapat digunakan pegawai maka sangat sulit pegawai untuk menunjukkan prestasi kerja. Fasilitas kerja sangat mendukung pelaksanaan kerja terutama dari hasil atau produk baik dari kuantitas maupun kualitas. Pegawai tidak akan dapat menghasilkan kinerja yang memadai apabila tidak tersedia fasilitas kerja yang memadai dan apabila pegawai tidak dapat menggunakannya dengan baik. Pegawai tidak akan mampu menghasilkan kualitas kerja yang baik tanpa dilengkapi dengan fasilitas kerja. Oleh sebab itu fasilitas kerja sangat menentukan pelaksanaan kerja pegawai terutama kinerja pegawai.

Pimpinan juga harus berupaya agar meminimalisir adanya konflik peran dalam organisasi, berusaha untuk memotivasi pegawai agar selalu bekerja dengan semangat dan penuh perhatian selanjutnya pimpinan harus mampu mengarahkan pegawai dalam penggunaan emosinya. Kecerdasan emosi memiliki daya yang dahsyat apabila digunakan secara poisitp.

Adapun Tujuan penulis melakukan penelitian ini adalah sebagai berikut :

1. Untuk mengetahui dan menganalisis pengaruh fasilitas kerja terhadap kinerja pegawai di Kantor Pelayanan Pajak Pratama Tebing Tinggi.

2. Untuk mengetahui dan menganalisis pengaruh konflik peran terhadap kinerja pegawai di Kantor Pelayanan Pajak Pratama Tebing Tinggi.

3. Untuk mengetahui dan menganalisis pengaruh motivasi kerja terhadap kinerja pegawai di Kantor Pelayanan Pajak Pratama Tebing Tinggi.

4. Untuk mengetahui dan menganalisis pengaruh kecerdasan emosional terhadap kinerja pegawai di Kantor Pelayanan Pajak Pratama Tebing Tinggi.

5. Untuk mengetahui dan menganalisis pengaruh fasilitas kerja, konflik peran, motivasi kerja dan kecerdasan emosional terhadap kinerja pegawai di Kantor Pelayanan Pajak Pratama Tebing Tinggi.

\section{Metode Penelitian \\ 2.1Populasi dan Sampel}


Sudjana (2009:324) mengemukakan: "Populasi adalah sekelompok individu yang mewakili satu atau lebih karakteristik umum yang menjadi pusat perhatian penelitian. Populasi bisa berupa semua individu yang mewakili pola kelakuan tertentu atau sebahagian dari kelompok itu. Populasi penelitian ini adalah semua pegawai Kantor Pelayanan Pajak Pratama Tebing Tinggi yang berjumlah 83 orang.

Penentuan sampel penelitian adalah apabila jumlah populasi di atas seratus responden, maka boleh diambil 10\%, 15\%, 20\% dan seterusnya apabila subjeknya kurang dari seratus, lebih baik diambil semua sehingga penelitiannya merupakan penelitian populasi. Arikunto (2011:71). Berdasarkan ketentuan tersebut, maka sampel penelitian sebanyak 82 orang.

\subsection{Pengujian Validitas}

Uji validitas digunakan untuk mengukur sah atau valid tidaknya suatu kuesioner. Suatu kuesioner dikatakan valid jika pertanyaan pada kuesioner mampu untuk mengungkapkan sesuatu yang akan diukur oleh kuesioner tersebut. Metode yang digunakan untuk menguji validitas adalah melakukan korelasi antar skor butir pertanyaan dengan total skor konstruk atau variabel. Pengujian validitas dilakukan dengan melakukan korelasi bilvariate antara masing-masing skor indikator dengan total skor konstruk. Hasil analisis korelasi bilvariate dengan melihat output Pearson Correlation, dengan ketentuan :

1. $r$ hitung $>r$ tabel, maka instrumen yang digunakan dinyatakan valid.

2. $r$ hitung $<\mathrm{r}$ tabel, maka instrumen yang digunakan dinyatakan tidak valid.

Tabel 1

Uji validitas variable fasilitas kerja

\begin{tabular}{|c|c|c|c|c|}
\hline Pertanyaan & Nilai Korelasi $(\mathbf{r})$ & r-tabel & Keterangan & Kesimpulan \\
\hline 1 & 0.580 & 0.396 & $\mathrm{r}_{\text {hitung }}>\mathrm{r}_{\text {tabel }}$ & Valid \\
\hline 2 & 0.422 & 0.396 & $\mathrm{r}_{\text {hitung }}>\mathrm{r}_{\text {tabel }}$ & Valid \\
\hline 3 & 0.623 & 0.396 & $\mathrm{r}_{\text {hitung }}>\mathrm{r}_{\text {tabel }}$ & Valid \\
\hline 4 & 0.703 & 0.396 & $\mathrm{r}_{\text {hitung }}>\mathrm{r}_{\text {tabel }}$ & Valid \\
\hline 5 & 0.624 & 0.396 & $\mathrm{r}_{\text {hitung }}>\mathrm{r}_{\text {tabel }}$ & Valid \\
\hline 6 & 0.744 & 0.396 & $\mathrm{r}_{\text {hitung }}>\mathrm{r}_{\text {tabel }}$ & Valid \\
\hline 7 & 0.679 & 0.396 & $\mathrm{r}_{\text {hitung }}>\mathrm{r}_{\text {tabel }}$ & Valid \\
\hline 8 & 0.501 & 0.396 & $\mathrm{r}_{\text {hitung }}>\mathrm{r}_{\text {tabel }}$ & Valid \\
\hline 9 & 0.729 & 0.396 & $\mathrm{r}_{\text {hitung }}>\mathrm{r}_{\text {tabel }}$ & Valid \\
\hline 10 & 0.533 & 0.396 & $\mathrm{r}_{\text {hitung }}>\mathrm{r}_{\text {tabel }}$ & Valid \\
\hline
\end{tabular}

Tabel 2

Uji validitas variable konflik peran

\begin{tabular}{|c|c|c|c|c|}
\hline Pertanyaan & Nilai Korelasi (r) & r-tabel & Keterangan & Kesimpulan \\
\hline 1 & 0.654 & 0.396 & $\mathrm{r}_{\text {hitung }}>\mathrm{r}_{\text {tabel }}$ & Valid \\
\hline 2 & 0.772 & 0.396 & $\mathrm{r}_{\text {hitung }}>\mathrm{r}_{\text {tabel }}$ & Valid \\
\hline 3 & 0.508 & 0.396 & $\mathrm{r}_{\text {hitung }}>\mathrm{r}_{\text {tabel }}$ & Valid \\
\hline 4 & 0.716 & 0.396 & $\mathrm{r}_{\text {hitung }}>\mathrm{r}_{\text {tabel }}$ & Valid \\
\hline 5 & 0.463 & 0.396 & $\mathrm{r}_{\text {hitung }}>\mathrm{r}_{\text {tabel }}$ & Valid \\
\hline 6 & 0.659 & 0.396 & $\mathrm{r}_{\text {hitung }}>\mathrm{r}_{\text {tabel }}$ & Valid \\
\hline 7 & 0.397 & 0.396 & $\mathrm{r}_{\text {hitung }}>\mathrm{r}_{\text {tabel }}$ & Valid \\
\hline 8 & 0.461 & 0.396 & $\mathrm{r}_{\text {hitung }}>\mathrm{r}_{\text {tabel }}$ & Valid \\
\hline 9 & 0.629 & 0.396 & $\mathrm{r}_{\text {hitung }}>\mathrm{r}_{\text {tabel }}$ & Valid \\
\hline 10 & 0.740 & 0.396 & $\mathrm{r}_{\text {hitung }}>\mathrm{r}_{\text {tabel }}$ & Valid \\
\hline
\end{tabular}

Sumber : Hasil pengolahan Data Melalui SPSS 21, 2019

Tabel 3

Uji validitas variable motivasi kerja

\begin{tabular}{|c|c|c|c|c|}
\hline Pertanyaan & Nilai Korelasi $(\mathbf{r})$ & r-tabel & Keterangan & Kesimpulan \\
\hline 1 & 0.609 & 0.396 & $\mathrm{r}_{\text {hitung }}>\mathrm{r}_{\text {tabel }}$ & Valid \\
\hline 2 & 0.612 & 0.396 & $\mathrm{r}_{\text {hitung }}>\mathrm{r}_{\text {tabel }}$ & Valid \\
\hline 3 & 0.616 & 0.396 & $\mathrm{r}_{\text {hitung }}>\mathrm{r}_{\text {tabel }}$ & Valid \\
\hline 4 & 0.728 & 0.396 & $\mathrm{r}_{\text {hitung }}>\mathrm{r}_{\text {tabel }}$ & Valid \\
\hline
\end{tabular}




\begin{tabular}{|c|c|c|c|c|}
\hline Pertanyaan & Nilai Korelasi (r) & r-tabel & Keterangan & Kesimpulan \\
\hline 5 & 0.712 & 0.396 & $\mathrm{r}_{\text {hitung }}>\mathrm{r}_{\text {tabel }}$ & Valid \\
\hline 6 & 0.682 & 0.396 & $\mathrm{r}_{\text {hitung }}>\mathrm{r}_{\text {tabel }}$ & Valid \\
\hline 7 & 0.511 & 0.396 & $\mathrm{r}_{\text {hitung }}>\mathrm{r}_{\text {tabel }}$ & Valid \\
\hline 8 & 0.478 & 0.396 & $\mathrm{r}_{\text {hitung }}>\mathrm{r}_{\text {tabel }}$ & Valid \\
\hline 9 & 0.401 & 0.396 & $\mathrm{r}_{\text {hitung }}>\mathrm{r}_{\text {tabel }}$ & Valid \\
\hline 10 & 0.456 & 0.396 & $\mathrm{r}_{\text {hitung }}>\mathrm{r}_{\text {tabel }}$ & Valid \\
\hline
\end{tabular}

Sumber : Hasil pengolahan Data Melalui SPSS 21, 2019

Tabel 4

Uji validitas variable kecerdasan emosional

\begin{tabular}{|c|c|c|c|c|}
\hline Pertanyaan & Nilai Korelasi (r) & r-tabel & Keterangan & Kesimpulan \\
\hline 1 & 0.522 & 0.396 & $\mathrm{r}_{\text {hitung }}>\mathrm{r}_{\text {tabel }}$ & Valid \\
\hline 2 & 0.541 & 0.396 & $\mathrm{r}_{\text {hitung }}>\mathrm{r}_{\text {tabel }}$ & Valid \\
\hline 3 & 0.574 & 0.396 & $\mathrm{r}_{\text {hitung }}>\mathrm{r}_{\text {tabel }}$ & Valid \\
\hline 4 & 0.730 & 0.396 & $\mathrm{r}_{\text {hitung }}>\mathrm{r}_{\text {tabel }}$ & Valid \\
\hline 5 & 0.658 & 0.396 & $\mathrm{r}_{\text {hitung }}>\mathrm{r}_{\text {tabel }}$ & Valid \\
\hline 6 & 0.592 & 0.396 & $\mathrm{r}_{\text {hitung }}>\mathrm{r}_{\text {tabel }}$ & Valid \\
\hline 7 & 0.521 & 0.396 & $\mathrm{r}_{\text {hitung }}>\mathrm{r}_{\text {tabel }}$ & Valid \\
\hline 8 & 0.484 & 0.396 & $\mathrm{r}_{\text {hitung }}>\mathrm{r}_{\text {tabel }}$ & Valid \\
\hline 9 & 0.397 & 0.396 & $\mathrm{r}_{\text {hitung }}>\mathrm{r}_{\text {tabel }}$ & Valid \\
\hline 10 & 0.476 & 0.396 & $\mathrm{r}_{\text {hitung }}>\mathrm{r}_{\text {tabel }}$ & Valid \\
\hline
\end{tabular}

Sumber : Hasil pengolahan Data Melalui SPSS 21, 2019

Tabel 5

Uji validitas variable kinerja pegawai

\begin{tabular}{|c|c|c|c|c|}
\hline Pertanyaan & Nilai Korelasi $(\mathbf{r})$ & $\mathbf{r}$-tabel & Keterangan & Kesimpulan \\
\hline 1 & 0.643 & 0.396 & $\mathrm{r}_{\text {hitung }}>\mathrm{r}_{\text {tabel }}$ & Valid \\
\hline 2 & 0.479 & 0.396 & $\mathrm{r}_{\text {hitung }}>\mathrm{r}_{\text {tabel }}$ & Valid \\
\hline 3 & 0.641 & 0.396 & $\mathrm{r}_{\text {hitung }}>\mathrm{r}_{\text {tabel }}$ & Valid \\
\hline 4 & 0.534 & 0.396 & $\mathrm{r}_{\text {hitung }}>\mathrm{r}_{\text {tabel }}$ & Valid \\
\hline 5 & 0.548 & 0.396 & $\mathrm{r}_{\text {hitung }}>\mathrm{r}_{\text {tabel }}$ & Valid \\
\hline 6 & 0.490 & 0.396 & $\mathrm{r}_{\text {hitung }}>\mathrm{r}_{\text {tabel }}$ & Valid \\
\hline 7 & 0.555 & 0.396 & $\mathrm{r}_{\text {hitung }}>\mathrm{r}_{\text {tabel }}$ & Valid \\
\hline 8 & 0.548 & 0.396 & $\mathrm{r}_{\text {hitung }}>\mathrm{r}_{\text {tabel }}$ & Valid \\
\hline 9 & 0.405 & 0.396 & $\mathrm{r}_{\text {hitung }}>\mathrm{r}_{\text {tabel }}$ & Valid \\
\hline 10 & 0.627 & 0.396 & $\mathrm{r}_{\text {hitung }}>\mathrm{r}_{\text {tabel }}$ & Valid \\
\hline
\end{tabular}

Sumber : Hasil pengolahan Data Melalui SPSS 21, 2019

Dari table diatas menunjukkan bahwa seluruh pertanyaan pada setiap variabel telah memenuhi syarat validitas, yaitu $r$ hitung $>r$ tabel, dimana $r$ tabel $=0.396$. Oleh sebab itu, indikator - indikator tersebut dapat digunakan untuk mengukur variabel penelitian.

\subsection{Uji Asumsi Klasik}

\subsubsection{Uji Normalitas}

Uji normalitas bertujuan untuk mengetahui apakah data penelitian berdistribusi normal atau tidak, karena model regresi yang baik adalah model regresi yang berdistribusi normal.Menurut Wijaya (2011:130), untuk menentukan normal atau tidak dapat dilihat dari 2 cara yaitu:
1. Grafik normal pola menunjukkan penyebaran titik-titik di sekitar garis diagonal, dan mengikuti arah garis diagonal mengindikasikan model regresi memenuhi asumsi normal.

2. Apabila output histogram memenuhi atau mendekati kurva normal.

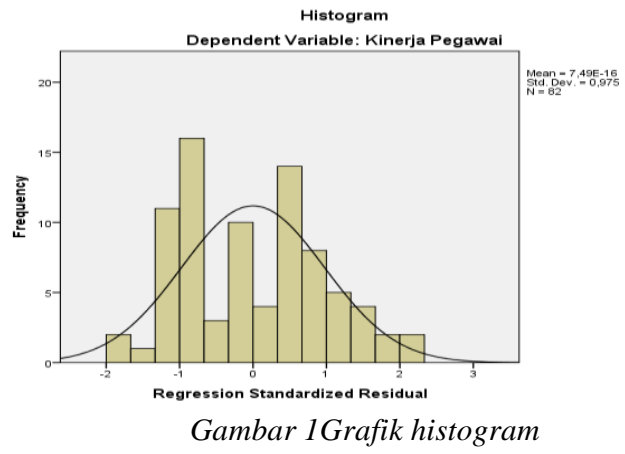


Selain gambar histogram dapat juga dilihat dari Normal plot sebagaimana berikut ini

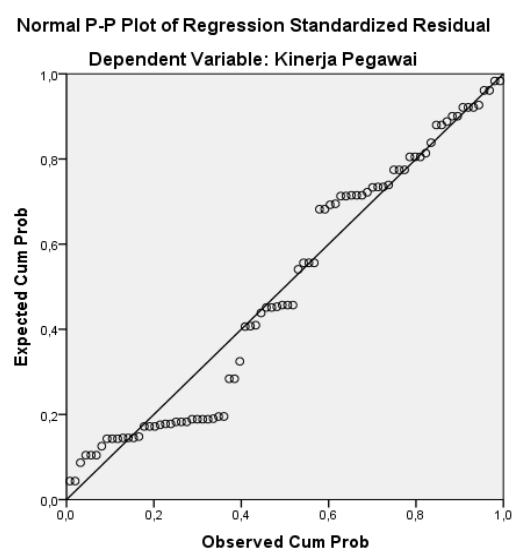

Gambar 2 Normal Plot

Berdasarkan gambar histogram di atas dapat dilihat distribusi mendekati normal.Selanjutnya grafik Plot menunjukkan penyebaran titik-titik disekitar garis diagonal dan mengikuti arah garis diagonal, mengindikasikan model regresi memenuhi asumsi normalitas.

\subsubsection{Uji Multikolinearitas}

Model uji regresi yang baik selayaknya tidak terjadi multikolinieritas. Untuk mendeteksi apakah model regresi yang dipakai bebas dari permasalahan multikolinearitas dapat dilihat aturan sebagaimaa disebutkan Wijaya : (2011:121)

a) Nilai $R^{2}$ yang dihasilkan oleh suatu estimasi model regresi sangat tinggi, tapi secara individual variabel bebas banyak yang tidak signifikan mempengaruhi variabel terikat.

b) Besar VIF (Vaiance Inflation Factor) dan toleransi, dimana VIF tidak lebih dari 10 dan nilai toleransi tidak kurang dari 0,1 .

Tabel 6

Uji Multikolinearitas

\begin{tabular}{|ll|r|r|r|}
\hline \multirow{2}{*}{ Model } & \multirow{2}{*}{ Sig. } & \multicolumn{2}{|c|}{ Collinearity Statistics } \\
\cline { 4 - 5 } & (Constant) &, 000 & & \multicolumn{1}{c|}{ VIF } \\
\hline & Fasilitas kerja &, 344 &, 010 & 1,281 \\
& Konflik Peran &, 912 &, 009 &, 112 \\
& Motivasi Kerja &, 001 &, 394 & 2,540 \\
& Kecerdasan emosional &, 000 &, 209 & 4,787 \\
\hline
\end{tabular}

Berdasarkan tabel di atas terlihat bahwa besarnya nilai VIF masing-masing variabel adalah 1,28, 0,112, 2,54 dan 4,78 dimana $<10$ yang berarti multikoliniearitas dapat ditoleransi.

\subsubsection{Uji Heteroskedastisitas}

Cara untuk melihat adanya problem heterokedastisitas adalah dengan melihat grafik plot antara nilai prediksi terikat dengan residualnya. Cara menganalisisnya adalah : dengan melihat apakah titik-titik memiliki pola tertentu yang teratur seperti bergelombang, melebar kemudian menyempit. Jika terjadi maka mengindikasikan terdapat heterokedatisitas.Jika tidak terdpat pola tertentu yang jelas serta titik-titik menyebar di atas dan di bawah angka 10 pada sumbu Y maka mengindikasikan tidak terjadi heterokedastisitas.

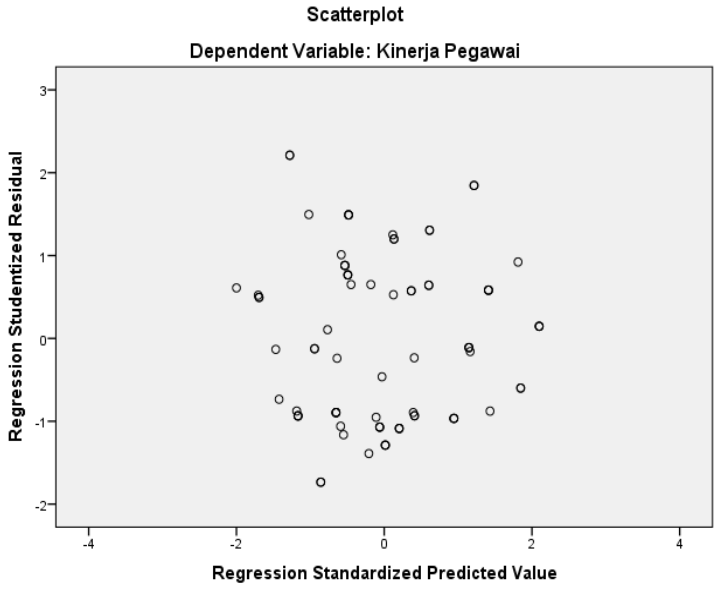

Gambar 3Uji heteroskedastisitas

\subsection{Analisis Regresi Linear Berganda}

Analisis Regresi Linier Berganda antara Fasilitas Kerja, Konflik Peran, Motivasi Kerja Dan Kecerdasan Emosional Terhadap Kinerja Pegawai Di Kantor Pelayanan Pajak Pratama Tebing Tinggi, dapat dilihat dari persamaan regresinya, dan dari output program SPSS diperoleh data sebagai berikut. 
Tabel 7

Koefisien regresi

\begin{tabular}{|c|c|c|c|c|c|}
\hline \multirow{2}{*}{ Model } & \multicolumn{2}{|c|}{ Unstandardized Coefficients } & $\begin{array}{l}\text { Standardized } \\
\text { Coefficients }\end{array}$ & \multirow{2}{*}{$\mathrm{t}$} & \multirow{2}{*}{ Sig. } \\
\hline & $\mathrm{B}$ & Std. Error & Beta & & \\
\hline $1 \quad$ (Constant) & 7,034 & 1,288 & & 5,463 &, 000 \\
\hline Fasilitas kerja & ,344 &, 362 & ,382 & 1,953 & ,344 \\
\hline Konflik Peran & ,043 & ,389 & ,047 & ,112 & ,912 \\
\hline M0tivasi Kerja & 201 & 057 & ,224 & 3,534 & ,001 \\
\hline Kecerdasan emosional & 320 &, 080 & 349 & 4,011 &, 000 \\
\hline
\end{tabular}

Berdasarkan Tabel 7 diatas dapat dibuat persamaan regresi sebagai berikut :

$$
Y=7.034+0.344 X_{1}+
$$

$0.043 X_{2}+0.201 X_{3}+0.320 X_{4}$

Persamaan di atas menunjukkan konstanta bernilai positip dan nilai koefisien regresi Fasilitas kerja,Konflik peran, Motivasi kerja dan kecerdasan emosional positip, Hal ini memberi gambaran bahwa perubahan rata-rata variabel Kinerja Pegawai (Y) tergantung dari perubahan variabel Fasilitas kerjakerja $\left(X_{1}\right)$, Konflik peran $\left(\mathrm{X}_{2}\right)$ Motivasi kerja $\left(\mathrm{X}_{3}\right)$ dan kecerdasan emosional. Artinya apabila Fasilitas kerja, Konflik peran, Motivasi kerja dan kecerdasan emosional ditingkatkan (semakin baik) akan diikuti perubahan/kinerja pegawai dan apabila konflik peran dikurangi akan meningkatkan kinerja pegawai

\subsection{Uji Signifikan Simultan (Uji F)}

Uji F (uji simultan) dilakukan untuk melihat pengaruh variabel bebas terhadap variabel terikatnya secara serempak. Cara yang digunakan adalah dengan melihat level of significant $(=0,05)$. Jika nilai signifikansi lebih kecil dari 0,05 maka $\mathrm{H} 0$ ditolak dan $\mathrm{Ha}$ diterima.

Tabel 8

Uji F

ANOVA

\begin{tabular}{|rl|r|r|r|r|r|}
\hline Model & & Sum of Squares & \multicolumn{1}{|c|}{ df } & Mean Square & F & Sig. \\
\hline & Regression & 1181.860 & 4 & 295.465 & 138.565 & $.000^{\circ}$ \\
\cline { 3 - 7 } & Residual & 164.189 & 77 & 2.132 & & \\
& Total & 1346.049 & 81 & & & \\
\hline
\end{tabular}

a. Dependent Variable: Kinerja Pegawai

b. Predictors: (Constant), Kecerdasan emosional, Motivasi Kerja, Fasilitas kerja, Konflik Peran

Berdasarkan analisis varians (Anova) pada table 8 diketahui nilai F-hitung sebesar 138.565sedangkan nilai F-tabel (Lampiran) dengan $\mathrm{dk}$ pembilang 4 dan $\mathrm{dk}$ penyebut 77 adalah sebesar 2,48 dimana F-hitung > F tabel $(138,565>2,48)$ maka dapat disebutkan bahwa secara bersama-sama (multiple) terdapat pengaruh yang signifikan Fasilitas kerja, Konflik peran, Motivasi kerja dan kecerdasan emosionalterhadap kinerja pegawai. Dengan demikian hipotesis yang diajukan diterima kebenarannya

\subsection{Uji Signifikan Parsial (t)}

Uji Parsial (Uji t) menunjukkan seberapa jauh variabel bebas secara individual menerangkan variasi pengujian ini dilakukan dengan menggunakan tingkat signifikansi 5\%.

Tabel 9

Uji t

Coefficients $^{\mathrm{a}}$

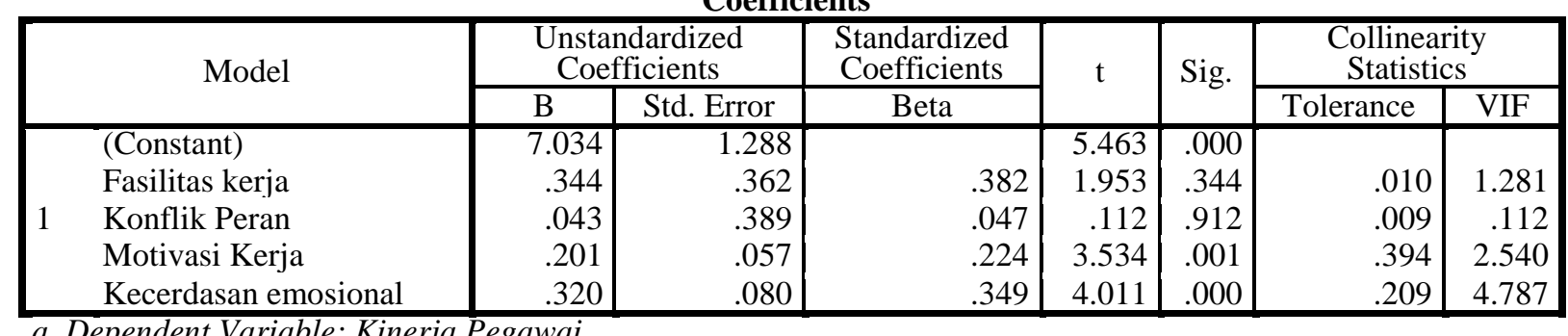

a. Dependent Variable: Kinerja Pegawai 
a) Pengaruh fasilitas kerja terhadap kinerja pegawai. Nilai $t_{\text {hitung }}>t_{\text {tabel }}(1.953>1.665)$ dengan nilai signifikan sebesar $0.344>0.05$ yang berarti bahwa fasilitas kerja berpengaruh tidak signifikan terhadap kinerja pegawai.

b) Pengaruh konflik peran terhadap kinerja pegawai. Nilai $t_{\text {hitung }}<\mathrm{t}_{\text {tabel }}(0.112<1.665)$ dengan nilai signifikan sebesar $0.912>0.05$ yang berarti bahwa konflik peran tidak berpengaruh dan tidak signifikan terhadap kinerja pegawai.

c) Pengaruh motivasi kerja terhadap kinerja pegawai. Nilai $t_{\text {hitung }}>t_{\text {tabel }}(3.534>1.665)$ dengan nilai signifikan sebesar $0.001<0.05$ yang berarti bahwa motivasi kerja berpengaruh positif dan signifikan terhadap kinerja pegawai.

d) Pengaruh kecerdasan emosional terhadap kinerja pegawai. Nilai $t_{\text {hitung }}>t_{\text {tabel }}(4.011>$ $1.665)$ dengan nilai signifikan sebesar 0.000 $>0.05$ yang berarti bahwa kecerdasan emosional berpengaruh positif dan signifikan terhadap kinerja pegawai.

\subsection{Uji Determinasi (R Square)}

Analisis koefisien determinasi ini digunakan untuk mengetahui persentase besarnya variasi pengaruh variabel bebas terhadap variabel terikat.

Tabel 10

Uji Determinan

Model Summary ${ }^{\mathrm{b}}$

\begin{tabular}{|l|r|r|r|r|r|}
\hline Model & \multicolumn{1}{|c|}{$\mathrm{R}$} & R Square & $\begin{array}{c}\text { Adjusted R } \\
\text { Square }\end{array}$ & $\begin{array}{c}\text { Std. Error of the } \\
\text { Estimate }\end{array}$ & Durbin-Watson \\
\hline 1 & $.937^{\mathrm{a}}$ & .878 & .872 & 1.46025 & 2.025 \\
\hline
\end{tabular}

a. Predictors: (Constant), Kecerdasan emosional, Motivasi Kerja, Fasilitas kerja, Konflik Peran

b. Dependent Variable: Kinerja Pegawai

Berdasarkan tabel 10 di atas menunjukkan bahwa angka adjusted $R$ Square 0,872 yang disebut koefisien determinasi dan artinya bahwa 87.2\% kinerja pegawai dapat diperoleh dan dijelaskan oleh kecerdasan emosional, motivasi kerja, fasilitas kerja, konflik peran. Sedangkan sisanya $100 \%-87.2 \%=13,8 \%$ dijelaskan oleh faktor lain atau variabel diluar model.

\section{Kesimpulan}

Berdasarkan pada analisis dan evaluasi data di

1. Fasilitas kerja berpengaruh tidak signifikan terhadap kinerja pegawai Kantor Pelayanan Pajak Pratama Tebing Tinggi dengan nilai $t_{\text {hitung }}>t_{\text {tabel }}(1,953>1,67)$.

2. Konflik peran tidak berpengaruh dan tidak signifikan terhadap kinerja pegawai Kantor Pelayanan Pajak Pratama Tebing Tinggi dengan nilai $t_{\text {hitung }}>t_{\text {tabel }}(0,112<1,67)$.

3. motivasi kerja berpengaruh positif dan signifikan terhadap kinerja pegawai Kantor Pelayanan Pajak Pratama Tebing Tinggi dengan nilai $t_{\text {hitung }}>t_{\text {tabel }}(3,53>1,67)$

4. kecerdasan emosional berpengaruh positif dan signifikan terhadap kinerja pegawai Kantor Pelayanan Pajak Pratama Tebing Tinggi dengan nilai $t_{\text {hitung }}>t_{\text {tabel }}(4,01>$ 1,67).

5. Nilai $F_{\text {hitung }}>F_{\text {tabel }}(138,565>2,48)$ hal ini menyatakan bahwa secara bersama-sama (multiple) terdapat pengaruh positif dan signifikan fasilitas kerja, konflik peran, motivasi kerja dan kecerdasan emosional terhadap kinerja pegawai Kantor Pelayanan Pajak Pratama Tebing Tinggi. Dengan demikian hipotesis yang diajukan diterima kebenarannya.

\section{DAFTAR PUSTAKA}

Albin, Rochelle Semmel, 2009, Emosi, Bagaimana Mengenal, Menerima dan

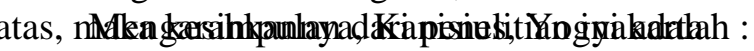

Arikunto, Suharsimi, 2011, Prosedur Penelitian Suatu Pendekatan Praktek. Jakarta: Rineka Cipta.

Corey, Gerald, 2013, Teori dan Praktek Konseling dan Psikoterapi, Penerjemah F. Koswara, PT. Refika Aditama, Jakarta:

Ginanjar, Ari, 2015, Rahasia Sukses Membangun Kecerdasan emosi dan Spritual, Jakarta: Arga.

Gouzali Saydam, 2012, Kamus Istilah Kepegawaian, Jakarta : Bina Aksara.

Irawan, 2013. Pengantar Ekonomi Perusahaan, Yogyakarta : UGM.

Kartono, Kartini, 2010, Teori Kepribadian, Penerbit Alumni, Bandung,

Lewis, Ramon, 2012, Dilema Kedisiplinan, Gramedia, Widya Sarana Indonesia, Jakarta

Mangkunegara, A. 2010, Evaluasi Kinerja SDM, Rafika Aditama, Bandung. 
Martin, Anthony Dio, 2014, Smart Emotion, Mesmbangun Kecerdasan Emosi, , PT. Gramedia Pustaka Utama, Jakartta.

Mitrani, Alain, 2009, Manajemen Sumber Daya Manusia Berdasarkan Kompetensi, Jakarta : Pustaka Utama Grafiti

Moenir, A. S,2010 : Pendekatan Manusia dan Organisasi Terhadap Pembinaan Kepegawaian,.Gunung Agung, Jakarta

---------, 2012, Manajemen Pelayanan Umum di Indonesia, Jakarta : Bina Aksara.

Moekijat, 20012, Manajemen Sumber daya Manusia. Jakarta : Rineka Cipta

Rahayu, Irma, 2014, Emosional Healing Therapy, Gramedia Widiasarana Indodnesia, Jakarta

Ranupandojo, Heidjrahman, et. al, 2012. Manajemen Personalia, BPFE, Yogyakarta

Rohani Ahmad, 2011. Pengelolaan Pengajaran, Rineka Cipta, Jakarta

Sedarmayanti, 2011, Sumberdaya Manusia dan Produktivitas Kerja. Bandung, : Ilham Jaya.

Siagian SP, 2010, Manajemen Sumber Daya Manusia, Edisi Revisi, PT. Bumi Aksara, Jakarta.

Sudjana, 2013, Metoda Statistika, Tarsito, Bandung.

Sugiyono, 2010, Metode Peneleitian Administrasi, Alfabeta, Bandung

Tangkilisan, Hessel Nogi, S, 2015, Manajemen Publik, Jakarta : PT. Grasindo

Thoha, Miftah, 2011. Prilaku Organisasi, Raja Grafindo Persada, Jakarta

Tulus, 2009, Prilaku dan Prestasi, Grasindo, Jakarta

Widodo, Joko, 2011, Telaah Dimensi Akuntabilitas dan Kontrol Birokrasi Pada Era Desentralisasi dan otonomi Daerah, Surabaya: Insan Cendekia

Wijaya Tony, 2011, Cepar Menguasai SPSS Untuk Olah \& Interpretasi Data Penelitian, Cahaya Atma Yogyakarta

Winardi, 2012. Manajemen Prilaku Organisasi, PT. Citra Aditya, Bandung 